\title{
MOTIVASI BERCADAR MAHASISWI INSTITUT AGAMA ISLAM NEGERI SURAKARTA DALAM TINJAUAN SOSIOLOGI ISLAM
}

\author{
Faridhatun Nikmah \\ Tadris Bahasa Indonesia, Fakultas Adab dan Bahasa \\ Institut Agama Islam Negeri Surakarta \\ faridhatunnikmah28@gmail.com
}

Received: 05-11-2020 /Accepted: 26-12-2020 / Doi: https://doi.org/10.32923/sci.v5i1.1458

\begin{abstract}
The phenomenon of women with claws often gets negative views. This is because people who think that the veil is identical to fanatics and radicals against religion. Therefore, many communities reject the existence of women with claws. Not only the community refused, but some campuses also strictly prohibited students from wearing veils. This is so as not to happen unwanted things. Therefore, this research needs to be done. This study aims to find out the motivations of students of the State Islamic Institute of Surakarta in a review of Islamic sociology. This research uses qualitative method with data retrieval technique in the form of observation, interview, and literature study. The results of this study showed that students with claws at IAIN Surakarta were influenced by two motivations, namely intrinsic motivation and extrinsic motivation. Both motivations are more influenced by eccentric motivations, namely motivations that arise from outside parties such as close friends, family, environment, teachers, brothers, organizations and fashion trends While in the review of Islamic sociology due to beliefs against the objectivity bias of religious dogma as part of the truth.
\end{abstract}

Keywords: Veil, Motivation, Islamic Sociology, IAIN Surakarta

1. Pendahuluan

Penggunaan cadar pada wanita muslimah identik dengan jilbab yang berukuran besar dan dominan berwarna gelap. Cadar dianggap sebagai versi lanjutan dari jilbab. Permasalahan saat ini cadar sering kali dianggap sebagai atribut organisasi Islam fanatik, fundamental, garis keras yang dikaitkan dengan terorisme (Ratri, 20011).

Salah satu perguruan tinggi yang menjadi perhatian publik dalam kasus terorisme adalah IAIN Surakarta. Perguruan tinggi tersebut pernah terjadi adanya penangkapan Densus 88 Anti Teror Mabes Polri terhadap kasus yang berinisial KF. KF terlibat jejaring terorisme. Seperti yang termuat pada artikel Kompas.com, terbitan 14 Desember 2016 yang menyebutkan bahwa puluhan mahasiswa IAIN Surakarta menggelar unjuk rasa di depan rektor IAIN Surakarta. Tujuan dari unjuk rasa tersebut menolak gerakan terorisme dan radikalisme (Wismabrata, 2016).

Selain itu, di UMS juga pernah terjadi kasus terorisme. Bahrun Naim adalah salah satu anggota terorisme yang tertangkap oleh Densus 88 Anti Teror. Ia diduga membawa salah satu mahasiswi UMS semester akhir yang berinisial SL. Menurut tetangga dekatnya SL dibawa pergi oleh seorang lelaki yang berinisial BN ke Suria (Sunaryo, 2015).

Fenomena di atas tidak berhenti sampai di situ saja, melainkan terdapat fenomena besar. Fenomena tersebut terjadi ledakan bom. Pelaku utama dari kejadian tersebut adalah wanita bercadar. Menurut saksi bahwa pelaku utama dari kejadian tersebut adalah wanita yang mengenakan cadar dan baju berwarna gelap. Kejadian tersebut, menimbulkan stigma negatif bagi masyarakat terhadap wanita bercadar.

Adanya fenomena tersebut mengundang ketakutan besar pada dunia akademik, khususnya pada kampus Universitas Islam Negeri (UIN) Sunan Kalijaga Yogyakarta (Safitri, 2018: 1). Bahkan Rektor UIN Sunan Kalijaga mengeluarkan surat edaran Nomor B-1301/Un.02/R/AK.00.3/02/2018 terkait dengan adanya pembinaan mahasiswa bercadar. Harapan dari kegiatan tersebut adalah agar mahasiswi bercadar mau melepaskan cadarnya. Akan tetapi, jika mahasiswi tersebut masih tetap nekat memakai cadar. Maka secara tegas pihak rektor akan mengeluarkannya dari kampus (Sabandar, 2018: 2-4).

Peraturan tersebut, senada dengan aturan yang ditetapkan oleh Universitas Islam Negeri (UIN) Sunan Ampel. Kampus tersebut melarang mahasiswinya memakai cadar. Menurut Profesor Abdullah A'la selaku rektor UIN Sunan 
Ampel menerapkan aturan yang sama dengan UIN Sunan Kalijaga. Dari kedua aturan tersebut memiliki adanya perbedaan yaitu terletak pada penggunaan. Aturan yang ditetapkan tersebut bertujuan agar mahasiswinya tidak menggunakan cadar di daerah kampus kecuali di luar daerah kampus mahasiswi bebas bercadar (Dikwis, 2018: 1).

Dari fenomena di atas dapat disimpulkan bahwa pihak kampus sangat menolak dan melarang keras mahasiswi memakai cadar. Tujuan dari penolakan dan pelarangan tersebut demi keamanan bersama, dan juga agar komunikasi dapat terjaga secara baik, serta agar tidak terjadinya pihak yang dirugikan.

Dibalik fenomena yang sering muncul di atas, ternyata mahasiswi memakai cadar tidak serta merta hanya mengenakan cadar. Melainkan memiliki adanya motivasi. Menurut Sarwono (2012: 24) bahwa motivasi adalah suatu dorongan individu yang bertujuan untuk membangkitkan diri seseorang. Wan \& Tan (2013: 100) bahwa motivasi adalah kesediaan dari individu dalam mengarahkan tingkat tinggi usaha untuk memenuhi kebutuhan individual. Penulis menyimpulkan bahwa motivasi adalah dorongan yang dari diri seseorang untuk mencapai tujuan tertentu. Dalam hal ini mahasiswi dalam memakai cadar ternyata memiliki motivasi tertentu sehingga penulis tertarik untuk meneliti.

Masalah dalam penelitian ini adalah apa motivasi yang melatarbelakangi mahasiswi bercadar di IAIN Surakarta dalam tinjauan sosiologi Islam? Dengan demikian, tujuan penelitian ini tentunya untuk mengetahui motivasi yang melatarbelakangi mahasiswi bercadar di IAIN Surakarta dalam tinjauan sosiologi Islam. Kebaruan dari penelitian ini adalah bahwa penelitian mengenai motivasi yang melatarbelakangi mahasiswi bercadar di IAIN Surakarta dalam tinjauan sosiologi Islam belum ada yang meneliti sehingga penulis tertarik untuk meneliti. Penulis lebih mengambil objek kajian di Surakarta karena di Surakarta banyak ditemui orang-orang bercadar khususnya mahasiswi. Selain itu, dalam penelitian ini ditemukan bahwa mahasiswi bercadar mampu meraih kejuaraan pencak silat.

Penelitian yang relevan dengan penelitian ini dilakukan oleh Muhamad Saprudin (2016) dengan judul Motivasi Pemakaian Jilbab Mahasiswi Islam Universitas Negeri Jakarta. Hasil dari penelitian ini menunjukkan bahwa faktor yang mempengaruhi motivasi terbagi menjadi empat yaitu psikologis, teologis, sosiologis, dan biologis. Persamaan dari penelitian ini menunjukkan bahwa penelitian ini sama-sama meneliti mengenai motivasi dan subjek penelitiannya adalah mahasiswi. Perbedaan dari penelitian ini dengan milik penulis adalah penelitian ini lebih mengambil objek jilbab sedangkan penulis lebih mengambil objek cadar yang kemudian ditinjau menggunakan sosiologi Islam.

Penelitian relevan lainnya juga dilakukan oleh Nawir \& Syarifuddin (2016) yang berjudul Persepsi Masyarakat tentang Perempuan Bercadar. Hasil dari penelitian ini menunjukkan bahwa pandangan masayarakat terhadap wanita bercadar sangat negatif bahkan sebagian masayarakat menolak keberadaannya di dalam masyarakat. Persamaan dari penelitian ini menunjukkan bahwa mahasiswi yang tidak memakai cadar sering mengucilkan atau menolak keberadaan mahasiswi yang bercadar. Perbedaan dari penelitian ini dengan milik penulis adalah bahwa penelitian ini lebih kepada persepsi masyarakat terhadap perempuan bercadar sedangkan milik penulis lebih kepada motivasi yang melatarbelakangi mahasiswi bercadar di IAIN Surakarta dalam tinjauan sosiologi Islam.

\section{Metode Penelitian}

Penelitian ini menggunakan metode kualitatif deskriptif yang dilakukan dengan cara mendeskripsikan fenomena yang diteliti untuk memecahkan permasalahan dalam penelitian. Sebagaimana yang dikemukakan oleh Sugiyono (dalam Nikmah, 2020: 220) metode kualitatif lebih mengutamakan makna. Dapat disimpulkan bahwa metode kualitatif deskriptif adalah metode yang melihat fenomena masalah yang kemudian didiskripsikan dan didukung adanya teori yang berkaitan dengan penelitian.

Sumber data yang digunakan dalam penelitian ini dengan mengambil lima narasumber mahasiswi yang memakai cadar di IAIN Surakarta. Narasumber tersebut antara lain LP, AS, SRHS, AF, dan TK. Teknik pemilihan informan penelitian ini adalah purposive sampling dengan cara mengambil narasumber yang sesuai dengan permasalahan yang diteliti (Nikmah, 2020: 220).

Teknik pengumpulan data penelitian ini melalui teknik observasi, wawancara, dan studi literature. Teknik analisis data dalam penelitian ini 1) observasi secara langsung di IAIN Surakarta 2) mewawancarai mahasiswi bercadar di IAIN Surakarta, 3) menyimak wawancara, 4) mencatat wawancara, 5) mengelompokkan sesuai dengan jenisnya, dan 6) kesimpulan. 


\section{Hasil dan Pembahasan}

\section{a. Motivasi Mahasiswi Bercadar}

Motivasi merupakan penggerak, keinginan, rangsangan, hasrat, pembangkit tenaga, alasan, dan dorongan dalam diri manusia. Motivasi adalah energi dasar yang terdapat dalam diri individu yang menentukan perilaku. Menurut Samsudin (2010: 281) mengemukakan bahwa motivasi adalah proses mempengaruhi atau dorongan yang berasal dari luar terhadap individu atau kelompok untuk melakukan sesuatu yang diinginkan. Motivasi adalah kesediaan yang dilakukan oleh seseorang untuk memenuhi kebutuhan individual (Wan \& Tan, 2013: 100). Suhardi (2013) membagi motivasi menjadi dua, yaitu motivasi intrinsik dan motivasi ekstrinsik.

\section{1) Motivasi intrinsik}

Motivasi intrinsik adalah motivasi yang timbul dari dalam diri sendiri. Munculnya motivasi tersebut tanpa adanya campur tangan dari pihak luar. Adapun faktor yang mempengaruhi motivasi intrinsik di antaranya adalah kebutuhan, harapan, dan minat.

a) Faktor yang dipengaruhi oleh minat diartikan sebagai suatu perasaan yang dimiliki oleh seseorang tanpa adanya pemicu dari orang lain. Sebagai mana hasil wawancara dengan TK. TK menyatakan bahwa Motivasi saya untuk menggunakan cadar adalah jatuh cinta pada cadar saat pertama kali bertemu di tengah perjalanan hijrah saya (Wawancara TK, 12 Februari 2019 ).

TK menyatakan bahwa motivasi bercadar TK dikarenakan adanya jatuh cinta saat melakukan hijrah. Hijrah diartikan sebagai perubahan sikap atau tingkah laku untuk menuju yang lebih baik. Sebagaimana yang dikemukakan oleh Ibnu Taimiyyah, Ibn Hajar al Asqalani serta Ibn Arabi (dalam Ahzami, 2006: 17) bahwa hijrah adalah perpindahan dari negeri kafir dalam keadaan darurat menuju negeri muslim. Dalam hal ini seseorang bercadar dipicu adanya hijrah yang tujuannya untuk mengubah dirinya ke arah yang lebih baik.

b) Faktor yang dipengaruhi oleh harapan diartikan sebagai seseorang yang termotivasi oleh adanya harapan yang bersifat pemuasan diri. Keberhasilan harapan tersebut mengakibatkan harga diri seseorang meningkat. Sebagaimana yang dikemukan oleh AF bahwa motivasi menggunakan cadar merupakan bentuk upaya untuk menjaga kehormatan diri sebagai seorang muslimah. Seperti disampaian partisipan berikut.

"Kalau menurut saya dulu mikirnya bahwa kaki itu kan sesuatu yang tidak menarik, tapi kok diwajibin pakai kaos kaki sedangkan wajah itu yang membuat orang tertarik saat melihat muka daripada kaki. Jadi, saya lebih melindungi diri dari fitnah. Karena wajah itu dapat membangkitkan syahwat bagi kaum adam sehingga saya terdorong memakai cadar di situ. "(Wawancara AF, 12 Februari 2019).

Motivasi bercadar muncul karena adanya pemaknaan bahwa cadar adalah titik pusat yang paling menarik. Partisipan beranggapan bahwa fungsi cadar bertujuan untuk menjaga seseorang dari perbuatan maksiat agar untuk tidak menimbulkan syahwat bagi kaum adam. Oleh karena itu AF memilih menutupi wajahnya dengan cadar. Sebagaimana pandangan madzhab Maliki yang mengemukakan bahwa wajah wanita bukanlah aurat dan, memakai cadar hukumnya adalah sunnah, dan akan menjadi wajib jika dikhawatirkan menimbulkan fitnah (Purnama, 2011: 1). Bahkan sebagian dari madzhab Maliki berpendapat bahwa seluruh tubuh wanita adalah aurat. Az-zarqaani berkata

"Aurat wanita di depan lelaki muslim ajnabi adalah seluruh tubuh selain wajah dan telapak tangan. Bahkan suara indahnya juga aurat. Sedangkan wajah, telapak tangan luar dan dalam, boleh dinampakkan dan dilihat oleh laki-laki walaupun wanita tersebut masih muda baik sekedar melihat ataupun untuk tujuan pengobatan. Kecuali jika khawatir timbul fitnah atau lelaki melihat wanita untuk berlezat-lezat, maka hukumnya haram, sebagaimana haramnya melihat amraad. Hal ini juga diungkapkan oleh Al Faakihaani dan Al Qalsyaani” (Syarh Mukhtashar Khalil, 176).

Dari hadis di atas dapat disimpulkan bahwa bagian seluruh tubuh wanita adalah aurat kecuali wajah dan telapak tangan. Dapat dihukumi haram jika jika seorang laki-laki melihat wanita untuk berlezat-lezatan.

c) Faktor yang dipengaruhi oleh kebutuhan diartikan sebagai seseorang yang melakukan kegiatan karena adanya faktor kebutuhan. Sebagaimana kutipan yang disampaikan informan AF. 
Faktor yang mempengaruhi saya dalam menggunakan cadar itu untuk menjaga diri dari godaan kaum karena kita sebagai kaum hawa perlu berhati-hati dan harus menjaga diri kita dengan sebaik mungkin dan wanita adalah hiasan utama (Wawancara AF, 12 Februari 2019).

Dari wawancara di atas partisipan AF memutuskan untuk bercadar dikarenakan untuk menjaga diri dari kaum adam. Kaum adam dijadikan sebagai faktor pemicu AF untuk bercadar. Hal tersebut agar AF merasa nyaman dengan adanya cadar yang dikenakan. Cadar dijadikan sebagai bentuk kebutuhan AF karena seorang wanita dijadikan sebagai hiasan utama. Sebagaimana yang dikemukakan oleh Rahmawati (2020: 1) bahwa dalam Islam wanita memiliki kedudukan yang paling tinggi. Allah SWT sangat menjaga harkat dan martabat seorang wanita yang salihah. Hal tersebut dibuktikan dengan banyaknya hadis yang menjelaskan keistimewaan dari seorang wanita. Salah satu hadis yang menyebutkan bahwa "Dunia adalah perhiasan, dan sebaik-baiknya perhiasan dunia adalah istri yang salihah." (HR. Muslim dari Abdullah bin Amr).

Dari hadis di atas sangat jelas bahwa wanita salih merupakan perhiasan dunia. Allah telah menciptakan wanita dengan keindahannya itu tidak hanya dinilai dari fisiknya saja, melainkan dari hati dan pemikirannya juga. Dan sebagai perhiasan, maka hendaknya perlu dijaga dan dirawat.

\section{2) Motivasi Ekstrinsik}

Motivasi ekstrinsik adalah motivasi yang timbul pada diri seseorang melalui pihak luar. Motivasi ini dipicu oleh adanya dorongan dari orang lain sehingga orang tersebut dapat termotivasi. Faktor yang mempengaruhi motivasi ekstrinsik di antranya adalah keluarga, saudara, teman, organisasi, dan tren atau fashion. Seperti tergambar dalam kutipan berikut.

Saya memakai cadar itu tulus dari hati.sendiri, sejak semester 1 itu pengen memakai cadar tapi belum mantap dan akhirnya meminta pertimbangan dari orang sekitar yang deket dengan saya mulai dari ustazah, ustad, saudara, bulek, dan lain sebagainya. Akhirnya mereka memberikan respon yang baik dan saya lebih mantap memakai cadar di semester 2 (Wawancara LP, 11 Desember 2019).

Motivasi saya untuk memakai cadar adalah untuk menjaga diri sendiri. Menurut saya lebih suka memakai cadar di lingkungan baru daripada lingkungan rumah karena kalau di lingkungan baru tidak semua orang tahu. Namun, kalau berada di lingkungan rumah saya lebih menyesuaikan lingkungan dan konteksnya karena tidak semua orang menganggap cadar itu wajib. Tapi ada beberapa orang menganggap cadar itu sunnah, mubah, dan sebagainya (Wawancara AS, 14 Februari 2019).

Beberapa kutipan di atas menunjukkan bahwa motivasi utama memakai cadar timbul dari diri sendiri. Tujuan utama memakai cadar untuk mendekatkan diri kepada Allah sehingga menimbulkan rasa aman. Hal tersebut dirasakan oleh AS yang merasa lebih nyaman memakai cadar di lingkungan baru. Menurutnya penggunaan cadar lebih mudah diterima di lingkungan baru daripada di lingkungan sendiri. Pada saat di rumah AS menyesuaikan konteks keluarganya terdapat variasi golongan sehingga AS lebih menghargai saudaranya yang tidak bercadar daripada mementingkan hawa nafsu. Selain itu, motivasi menggunakan cadar itu timbul dari teman dekat, lingkungan, dan organisasi. Seperti kutipan di bawah ini:

Motivasi untuk memakai cadar dari teman dan lingkungan, dan diorrganisasi daurah tahfidz. Pihak orang tua juga mensetujui ia memakai cadar (Wawancara SRHS, 11 Februari 2019).

Kutipan di atas menunjukkan bahwa teman. Teman memiliki porsi besar dalam mempengaruhi seseorang. karena saat menginjak usia remaja justru mudah terpengaruh dari teman daripada orang tua. Hal itu disebabkan adanya motivasi dua arah yang selalu terjalin setiap hari. Motivasi lingkungan disebabkan karena adanya kebiasaan, kebutuhan, atau pengakuan terhadap eksitensi masyarakat yang sudah menjadi budaya dan mau tidak mau kita harus mengikuti budaya yang ada sedangkan organisasi adalah suatu komunitas atau wadah yang digunakan untuk menyalurkan bakat yang sesuai dengan keinginan hati dan di dalamnya terdapat visi, misi, tujuan, dan sebagainya. Motivasi organisasi adalah suatu dorongan yang timbul dari komunitas yang memang sudah menjadikan aturan yang harus diikuti. Jadi teman, lingkungan, dan organisasi sangat mempengaruhi seseorang. Seperti kutipan di bawah ini:

Ya, berawal dari diri sendiri yang ingin mengubah diri saya menjadi yang lebih baik, Kemudian faktor dari bulek saya yang sejak saya SD sudah memakai cadar. Kemudian termotivasi oleh teman dekat saya (Wawancara LP, 12 Desember 2019). 
Faktor yang mempengaruhi memakai cadar itu memang dari sendiri kemudian saya langsung mencoba. Soalnya menurut saya memakai cadar itu lebih enak di lingkungan baru daripada di tempat tinggal yang saya tempati soalnya kalau di tempat tinggal saya masih buka tutup cadar karena menyesuaikan lingkungannya. Kalau di lingkungan baru kan gak banyak ada orang yang tahu jadi lebih enak aja. (Wawancara AS, 14 Februari 2019).

Faktor yang mempengaruhi partisipan LP memakai cadar salah satunya adalah diri sendiri. Dalam diri seseorang terdapat adanya icon yang kuat untuk mendorong keinginan seseorang. Kemudian faktor saudara dan juga teman dekat sedangkan partisipan (AS, 19) berpendapat bahwa lebih nyaman memakai cadar ditempat yang baru daripada di lingkung tempat tinggalnya. Karena jika di lingkungan baru tidak semua orang mengenal sedangkan kalau di lingkungan tempat tinggal itu tidak semua orang memakai cadar sehingga dalam pemakaian cadar menyesuaikan konteks.

Hasil penelitian menunjukkan bahwa motivasi bercadar lebih dominan motivasi pragmatis daripada motivasi ideologis. Motivasi ideologi dipengaruh adanya pemahaman yang lebih mengarah pada akhirat sedangkan motivasi pragmatis dipengaruhi oleh dorongan sosial seperti, kakak, teman dekat, keluarga, saudara, dan organisasi.

\section{b. Tinjauan Sosiologi Islam}

Sosiologi diartikan sebagai suatu ilmu yang berhubungan dengan interaksi manusia. Menurut Abdussalam (2014: 25) menyatakan bahwa sosiologi selain dijadikan sebagai disiplin ilmu yang luas juga terdapat adanya nilai strategis dalam mengembangkan proses kehidupan manusia. Hal tersebut dikarenakan adanya keberadaan manusia akan lebih terlihat dalam kebersamaannya dengan manusia lain atau lingkungan. Dalam hal ini kualitas manusia dapat dilihat melalui interaksinya baik dengan orang lain maupun lingkungannya.

Pendapat tersebut selaras dengan pendapat yang dikemukakan oleh Sampean (2018: 404) menyatakan bahwa sosiologi Islam adalah disiplin ilmu yang menganalisis konteks masyarakat muslim dengan berdasarkan data-data yang diperoleh dari sejarah Islam yang berupa Alquran dan Hadis. Hal tersebut dikarenakan Alquran dan Hadis terdapat ajaran-ajaran Islam yang kemudian dilakukan dengan cara dianalisis, ditafsir, dan disimpulkan. Sebagaimana yang dikemukakan oleh Safei (2017: 14) berpendapat bahwa Alquran tidak hanya sekadar kitab suci melainkan juga kitab pengetahuan yang dijadikan sebagai obor penerangan perjalanan peradaban manusia. Buku yang ditulis oleh Safei membuktikan bahwa Alquran dijadikan sebagai wahyu Allah yang di dalamnya terdapat banyak konsep dasar yang dapat dikembangkan menjadi sains sosial yang bertujuan untuk membangun peradaban manusia di masa yang akan datang.

Sebagaimana yang dikemukakan oleh Kuntowijoyo mengenai ilmu sosial profentik. Menurut Jurdi (2010: 13) bahwa kajian mengenai ilmu sosial profentik berupaya untuk melihat fenomena sosial bukan proses islamisasi ilmu itu sendiri. Tawaran yang diberikan oleh Kuntowijoyo mengenai keilmuan Islam bertujuan untuk kebaikan manusia dalam menjawab nilai-nilai keislaman. Kerangka pemikiran Kuntowijoyo menjadikan wahyu sebagai sumber dan dasar pengetahuan utama atau disebut sebagai strukturalisme trasendental. Struktur trasendental dijadikan sebagai kunci utama dalam mengimplementasikan humanisasi, liberasi, dan transendensi.

Keberadaan sosiologi Islam bertujuan untuk memetakan persoalan yang dihadapi oleh manusia. Dalam perspektif sosiologi Islam dimensi pola relasi sosial dalam fenomena keberagaman. Pola hubungan dibentuk berdasarkan hubungan struktur yang statistik dan dinamis. Hal tersebut dapat dilihat dari perbedaan keduanya.

Tabel 1. Struktur Statistik dan Dinamik

\begin{tabular}{|c|c|}
\hline Keagamaan dalam Struktur Statistik & Keagamaan dalam Struktur Dinamik \\
\hline Status dan peran & Intensitas relasi antar agama \\
\hline $\begin{array}{l}\text { Model hubungan patron-klien, kasta, dan } \\
\text { jemaah-ustaz, ulama-santri, nabi dan rasul- } \\
\text { umat, Allah-hamba }\end{array}$ & Pola struktur dalam rentan waktu tertentu \\
\hline Skematik & Dinamik \\
\hline Dapat dikuantifikasi & Desskriptif dapat dikuantifikasi \\
\hline Isu relasi & Adaptasi dan akomodasi \\
\hline $\begin{array}{l}\text { Dogma, pedoman hidup dan struktur } \\
\text { trasendental }\end{array}$ & Ajaran dan realita sosial \\
\hline
\end{tabular}


Dari perbedaan di atas dapat disimpulkan bahwa keberadaan sosiologi Islam adalah untuk melihat kelompok masyarakat Islam yang memiliki sistem budaya kemasyarakatan baik nilai, keyakinan, historis, dan moralitas. Dalam lingkup kajian sosiologi Islam dalam penelitian ini bertujuan untuk merefleksikan sikap keberagamaan umat Islam di Indonesia yang mberdasarkan adanya pola hubungan keberagamaan yang kompleks. Selain itu, adanya pola relasi yang terbentuk dalam determinasi negara terhadap umat, ketegangan konfliktual antara pemeluk agama Islam dengan yang lain. Pola hubungan tersebut disebabkan karena keyakinan terhadap bias objektivitas dogma agama sebagai bagian dari kebenaran. Bias dogma agama menyebabkan sikap eksklusivitas dan klaim otoritas kebenaran satu sama lain.

\section{Simpulan}

Dapat disimpulkan bahwa motivasi adalah suatu dorongan pada diri seseorang untuk melakukan sesuatu yang diinginkan. Motivasi terbagi menjadi dua, yaitu motivasi intrinsik dan motivasi ekstrinsik. Motivasi intrinsik adalah motivasi yang muncul dari dalam diri seseorang. Faktor yang mempengaruhi adanya motivasi intrinsik di antaranya adalah faktor kebutuhan, harapan, dan minat. Sedangkan motivasi ekstrinsik diartikan sebagai dorongan yang timbul dari pihak luar atau orang lain. Faktor yang mempengaruhi adanya motivasi ekstrinsik adalah dorongan dari keluarga, lingkungan, fashion, dan lain sebagainya. Dari penelitian di atas data yang paling banyak ditemukan bahwa kebanyakan mahasiswi IAIN Surakarta motivasi untuk mengenakan cadar dipengaruhi oleh motivasi ekstrinsik. Hal tersebut dikarenakan adanya dorongan dari keluarga, guru, lingkungan, organisasi, dan lain sebagainya. Sedangkan dalam tinjauan sosiologi Islam disebabkan karena keyakinan terhadap bias objektivitas dogma agama sebagai bagian dari kebenaran.

\section{SARAN}

\section{a. Bagi Subjek}

Masing-masing subjek diharapkan untuk meningkatkan aktivitas dan potensi yang dimiliki dan membuktikan bahwa cadar bukan sebagai hambatan untuk menjadi juara.

\section{b. Bagi keluarga}

Diharapkan lebih memahami dan menerima keputusan subjek untuk memakai cadar dan terlibat aktif dalam aktivitas dalam keluarga sehingga subjek mampu menjalankan pekerjaannya dengan baik.

\section{c. Bagi Mahasiswa}

Diharapkan mahasiswa dapat menerima subjek secara penuh sehingga subjek tidak merasa didiskriminasikan dalam lingkup perguruan tinggi.

\section{d. Bagi Masyarakat}

Diharapkan masyarakat dapat memperlakukan sama seperti individu lain dan mengajak subjek untuk terlibat dalam aktivitas atau pekerjaan di masyarakat, sehinga subjek dapat mengembangkan potensinya.

\section{e. Bagi Peneliti}

Penelitian ini dapat dijadikan sebagai sumber rujukan dalam penulisan sehingga dapat memperkaya khazanah keilmuan khususnya keislaman.

\section{Daftar Pustaka}

Abdussalam, A. (2014). Teori Sosiologi Islam (Kajian Sosiologis terhadap Konsep-Konsep Sosiologi dalam Alquran AlKarim). Jurnal Pendidikan Agama Islam, 12(1), 25-41.

Ahzami, S. J. (2006). Hijrah dalam Pandangan Alquran terjemahan Eko Yulianti. In Gema Insani Press (p. 17). Jakarta.

Dikwis. (2018). UIN Sunan Ampel juga Larang Mahasiswi Mengenakan Cadar. CNN Solo. Retrieved from https://www.cnnindonesia.com/nasional/20180306215851-20-280979/uin-sunan-ampel-juga-larang-mahasiswikenakan-cadar

Iskandar, A. S. (2013). Konstruksi Identitas Muslimah Bercadar. Artikel Ilmiah Hasil Penelitian Mahasiswa, 2(2), 1-12.

Jurdi, S. (2010). Sosiologi Islam \& Masyarakat Modern. Yogyakarta: Prenada Media.

Muhamad Saprudin, D. (2016). Motivasi Pemakaian Jilbab Mahasiswi Islam Universitas Negeri Jakarta. Jurnal Studi AlQur'an, 12(2), 182-193.

Nawir, M., \& Syarifuddin. (2016). Persepsi Masyarakat Tentang Perempuan Bercadar. Jurnal Equilibrium FKIP Unismuh Makassar, II(1), 117-126. 
Nikmah, F. (2020). Nilai-Nilai Pendidikan Karakter dalam Tradisi Apitan di Desa Serangan Kecamatan Bonang Kabupaten Demak. Handep Jurnal Sejarah Dan Budaya, 3(2), 215-232.

Purnama, Y. (2011). Hukum Memakai Cadar dalam Pandangan 4 Madzhab. Retrieved from https://muslim.or.id/6207hukum-memakai-cadar-dalam-pandangan-4-madzhab.html

Rahmawati, F. (2020, April). Merupakan Perhiasan Dunia, Ini 5 Hadis Rasulullah Tentang Istimewanya Seorang Wanita Salihah. Akurat.Co. Retrieved from https://akurat.co/news/id-1079548-read-merupakan-perhiasan-dunia-ini-5hadis-rasulullah-tentang-istimewanya-seorang-wanita-salihah

Ratri, L. (20011). Cadar, Media, dan Identitas Perempuan Muslim. Journal Universitas Diponegoro, 39(2), $29-37$. Retrieved from http://ejournal.undip.ac.id/index.ph p/forum/article/view/3155\%0ARudianto.

Sabandar, S. (2018). Alasan UIN Sunan Kalijaga Melarang Mahasiswi Bercadar. Yogyakarta. Retrieved from https://www.liputan6.com/regional/alasan-uin-sunan-kalijaga-melarang-mahasiswi-bercadar

Safei, A. A. (2017). Sosiologi Islam Transformasi Sosial Berbasis Tauhid. Jakarta: Simbiosis Rekatama.

Safitri, V. (2018). No Title. Fobia Cadar Di Dunia Akademik, p. 1.

Sampean. (2018). Sosiologi Islam Refleksi Atas Keberagaman Umat Islam di Indonesia Antar Dogma, Ajaran, dan Realita. Journal Islamic World and Politics, 2(2), 402-419.

Samsudin, S. (2010). Manajemen Sumber Daya Manusia. Bandung: Pustaka Setia.

Sarwono, S. W. (2012). Psikologi Remaja Edisi Revisi. PT Raja Grafindo Persada.

Suhardi. (2013). The Science Of Motivation Kitab Motivasi. Jakarta: PT. Elex Media Komputindo.

Sunaryo, A. (2015). Hilang, mahasiswi UMS diduga dibawa eks napi teroris ke Suriah. Merdeka.Com. Retrieved from https://www.merdeka.com/peristiwa/hilang-mahasiswi-ums-diduga-dibawa-eks-napi-teroris-ke-suriah.html

Wan Fauziah, W.Y., \& Tan, S. . (2013). Generation Differences in work Motivation: From Developing Country Persepctive. Journal of Economy, Management and Sosial Sciences, 2(4), 97-103.

Wismabrata, M. (2016). Satu Rekannya Ditangkap Densus Mahasiswa Demo Tolak Terorisme. Kompas.Com. Retrieved from

https://regional.kompas.com/read/2016/12/14/18380341/satu.rekannya.ditangkap.densus.mahasiswa.iain.surakarta .demo.tolak.terorisme

Wawancara. Lisa Puspitasari. Sukoharjo, 11 Desember 2019.

Wawancara. Anisa Sulastri. Solo, 14 Februari 2019.

Wawancara. Safira Rahima Hanggraeni Suparlan. Sragen, 11 Februari 2019.

Wawancara. Atika Faizal. Klaten, 12 Februari 2019.

Wawancara. Talita Karim. Solo, 12 Febru 